\title{
COGNITIVE AND METACOGNITIVE STRATEGIES IN ARABIC LISTENING LEARNING AND RELATIONSHIP WITH STUDENTS' PERSONALITY
}

\author{
Raden Ahmad Barnabas, Zainal Rafli, Yumna Rasyid \\ Universitas Negeri Jakarta, Indonesia \\ Jl. Rawamangun Muka, Rawamangun, Pulo Gadung, Jakarta, 13220, Indonesia \\ CorrespondingE-mail:barnabas@unj.ac.id
}

\begin{abstract}
The purpose of this study was to find the effect of learning strategies (metacognitive and cognitive strategies) and personality (intrinsic and extrinsic personality) on Arabic listening skills. It was experiment research with experimental methods by factorial $2 \times 2$ design. It used a 2 -way analysis variance design. The process of collecting data used questionnaires, tests, observations, and documentation. The results showed that there was a significant influence on Arabic listening ability with different personality levels. Personality differences in the application of listening learning strategies are closely related. Language learning varies depending on individual characteristics and variations in language learning outcomes associated with student characteristics. Cognitive and metacognitive strategies have a significant influence on the Arabic listening ability with different levels of personality types namely extrovert and introvert. Therefore, it can be concluded that different personalities will influence the level of different listening skills in Arabic. The results of the study recommend that the learning process of listening to Arabic using metacognitive and cognitive strategies can be varied with the concept of group learning and enrichment of vocabulary from the material presented.
\end{abstract}

Keywords: $\quad$ Arabic Listening, Cognitive Strategy, Extrovert, Introvert, Metacognitive Strategy

\section{Introduction}

Listening is one of the language skills and abilities that have an important role in everyone's life, especially when the listening process occurs in communication using foreign languages such as Arabic. It supports both everyday life and the academic context, for example in everyday life, it can be useful to build communication with the community as in the process of deliberation to express ideas. In the world of education can help students to get the latest information both that occurs in the country and abroad. From the results of Mendelson's research, it was found that "from the total time spent communicating, listening requires $40-50 \%$; speaking 25 - 
$30 \%$; reading $11-16 \%$; and writing 9\%. "1 This statement is a very important view of the successful implementation of Arabic learning specifically for listening courses. Language learning at the Arabic Language Department of Strat1-1 Program, State University Jakarta is directed in improving students' ability to communicate in Arabic properly and correctly, both verbally and writing. To realize this goal, the learning process of Arabic listening in the Arabic Language Education Study Program at State University Jakarta requires support from various parties such as lecturers, learning facilities and students. However, in reality, listening to learning, especially for secondsemester students as a follow-up process of listening in the first semester, still faced many obstacles.

The result of observation show that Arabic listening learning problem comes from students who are concerned with understanding the contents of the listening material itself, among others (a) students have difficulty distinguishing the letters and words in Arabic correctly, (b) the speech of the native speaker is assessed so fast and incomprehensible; (c) students have difficulty understanding the meaning of the contents of dialogue; (d) students have difficulty determining the conclusions of information heard; (e) students have not been able to reveal what has been heard and relate it to real-life; and (f) a minimal collection of Arabic vocabulary.

The findings of the first problem are in line with Goh's view. In a study specifically, Goh has examined students' perceptions of the problem of listening comprehension. ${ }^{2}$ Graham's study shows that each student has different views in facing listening difficulties. Many factors influence the difficulty in understanding the listening process. ${ }^{3}$

Arabic is unique and has a considerable degree of difficulty compared to other foreign languages. As has been studied in a previous study by Dakwar that in diglossia, two variations can be used in daily communication. ${ }^{4}$ Besides that, personality has influenced the learning process. There were two personality problems that should be considered by lecturers when designing learning activities in the classroom, namely (1) students who have introverted personality in absorbing material because it tends to be more silent; while (2) extrovert's personality has an in-depth understanding of the material so that when the learning strategy used does not meet the needs of students, it causes boredom during learning. When students have an introverted personality, the better their performance in listening. However, as revealed by the findings, there was no significant interaction between sex and introversion/extroversion or between

1 S. Yıldırım \& Ö. Yıldırım, "Yabanci Dil Öğreniminde Dinleme Becerisinin Önemi Ve Yabanci Dil Öğrenenlerin Yaşadiği Dinleme Anlama Problemleri: Bir Alanyazin Değerlendirmesi”, Abant İzet Baysal Üniversitesi Eğitim Fakültesi Dergisi, Vol. 16, No. 4, 2016.

2 C. C. Goh, "A cognitive perspective on language learners' listening comprehension problems", The system, Vol. 28, No. 1, 2000, 55-75.

${ }^{3}$ S. Graham, "Listening comprehension: The learners' perspective", The system, Vol. 34, No. 2, 2006, 165-182.

4 R. Khamis Dakwar, M.Ahmar, R.Farah, \& K. Froud, K, "Diglossic aphasia and the adaptation of the Bilingual Aphasia Test to Palestinian Arabic and Modern Standard Arabic", Journal of Neurolinguistics, Vol. 47, 2018, 131-144. 
introversion/extroversion and the age of students on listening skills. ${ }^{5}$ The second problem is related to learning strategies. The process of listening to learning is still teacher-centered. Students complete written assignments, then the teacher played back the recording and asked students to correct their wrong answers. These problems are difficult to be solved because the Arabic learning process for non-native speakers is influenced by many factors that should be able to integrate and harmonize in the learning process in the classroom. ${ }^{6}$ Therefore, Arabic learning requires a clear methodology by the context after creativity during the teaching and learning process. ${ }^{7}$

According to $\mathrm{Goh}^{8}$, a listening process like this is a process called "not teaching testing", so as to produce a product/output from "Student Listening," the teaching of listening should not only focus on the product but it must provide skills in stages as needed by students to develop listening skills so that they are able to listen beyond the topic and help students to develop their "metacognitive" knowledge and strategies, so they can listen to "Beyond the Topic".

The listening learning strategy proposed by O'Malley and Chamot ${ }^{9}$ is a metacognitive, cognitive and social or effective strategy. However, this study only offers metacognitive and cognitive strategies. Since both strategies are following the need for the completion of Arabic listening. In metacognitive strategies, the concept of listening teaching and learning are (1) selective attention; (2) self-monitoring; and (3) problem identification. Meanwhile cognitive strategies offering listening concepts which are: (1) rehearsal or repetition of the names of the items or objects that have been listened; (2) organization or classification of words, terminology, or concepts according to the semantic or syntactic characteristics that have been listened; (3) inferencing or the use of information in oral texts to predict the meanings of new linguistic items, predict results or consequences, or complete missing parts; (4) summarizing or synthesizing immediately anything that has been listened to ensure that information is understood and mastered; (5) deduction or application of rules to understand the language being listened; (6) imagery or the use of visual images to understand and remember new verbal information from listening; (7) transfer or use of known linguistic information to facilitate new learning tasks; and (8) elaboration or coupling of ideas contained in new information or integrating new ideas with information that has been known.

From the presentation of the two concepts of listening learning, it is assumed that it is appropriate to solve the Arabic listening problem. Due to the steps of both

${ }^{5}$ P. Alavinia, \& A. Sameei, "Potential Bonds between Extroversion/Introversion and Iranian EFL Learners' Listening Comprehension Ability", English Language Teaching, Vol. 5, No. 5, 2012, 19.

${ }^{6}$ B. A. S. Dajani, S. Mubaideen, \& F. M. A. Omari, "Difficulties of Learning Arabic for Nonnative Speakers", Procedia - Social and Behavioral Sciences, Vol. 114, 2014, 919-926.

${ }^{7}$ B. A. S. Dajani, "Teaching the Arabic Language: Towards a New Beginning that Stimulates Creativity", Procedia - Social and Behavioral Sciences, Vol. 192, 2015, 758-763.

8 C. Goh, "English Language Teaching Materials Theory and Practice. ed. Nigel Harwood", (Cambridge: Cambridge University Press, 2010).

${ }_{9}$ J. M. O’Malley \& A. U. Chamot, Learning Strategies in Second Language Acquisition, (Unites Stated of Americ: Cambridge University Press, 1995). 
approaches touch directly on the steps of listening learning. Metacognitive strategies require further thinking in learning that is looking for the right learning strategy for him, and passing reflection on learning independently. Only extroverted personalities are suitable and able to do that. The research conducted by Selamat and Sidhu reports the research findings taken from ongoing doctoral research studies to investigate the effects of metacognitive strategy training on comprehension skills listening to lectures by undergraduate students in Malaysia. ${ }^{10}$ The results of the same study state that better understanding becomes a personality trait, especially the Big-Five personality traits, to know about students' metacognitive awareness in learning a second language or a foreign language. ${ }^{11}$

In contrast, introverted students need more cognitive strategies. An introvert is an individual who likes to be alone, contemplate, read, write, and not really like hanging out with many people. They can work alone, full of concentration, and focus. ${ }^{12}$ From this condition, the listening learning process requires the application of a blend of learning strategies that can meet the needs of students who are extroverted and introverted. Research conducted by Vahdany, Akbari, and Askari is about the relationship between cognitive and metacognitive strategies. The findings of this study suggest that the use of cognitive and metacognitive strategies can explain the variation of listening ability and need to be encouraged, trained, and promoted by foreign language teachers. ${ }^{13}$ Thus, introverted and extroverted personality has a considerable influence on improving Arabic listening learning. The value of listening ability has a positive relationship with the introversion of the subject. ${ }^{14}$

In this study, the learning strategy that leads to understanding the contents of the learning material is direct listening. This means that the strategy used is not only fully oriented to the strategy. It raises the novelty of this experimental research. From the application of these two strategies which are associated with differences in student personality, they are also directed at the concept of systematic learning and selfregulated learning. Like as in Mohamed's study show that metacognition and selfregulation have a relationship with young children's achievement. ${ }^{15}$ Thus, the study can also find out how the harmony of cognitive and metacognitive strategy concepts can build awareness of the Arabic listening learning process.

10 S. Selamat, \& G. K. Sidhu, "Enhancing Listening Comprehension: The Role of Metacognitive Strategy Instruction (MetSI)", Procedia - Social and Behavioral Sciences, Vol. 90, 2013, 421430 .

11 H. $\ddot{z}$, The Importance of Personality Traits in Students: Perceptions of Metacognitive Awareness", Procedia - Social and Behavioral Sciences, Vol. 232, 2016, 655-667.

12 S. Dwi, “Kenali Dirimu, Yuk!", (Wonosari: Laksana, 2014).

${ }^{13}$ F. Vahdany, E. Akbari, F. Shahrestani, \& A. Askari, "The Relationship between Cognitive and Meta-cognitive Strategy Use and EFL Listening Test Performance", Theory and Practice in Language Studies, Vol. 6, No. 2, 2016, 385.

14 P. Alavinia \& A. Sameei, "Potential Bonds between Extroversion/Introversion and Iranian EFL Learners’ Listening Comprehension Ability”, English Language Teaching, Vol. 5, No. 5, $2012,19$.

15 A. H. H. Mohamed, "The Relationship Between Metacognition and Self-regulation in Young Children", Procedia - Social and Behavioral Sciences, Vol. 69, 2012, 477-486. 
Arabiyât Jurnal Pendidikan Bahasa Arab dan Kebahasaaraban, 6 (2), 2019

The purpose of this study is to know about the effect of personality types and learning strategies on Arabic listening learning ability. This study will attempt to answer the following research questions:

1. What is the difference between Arabic listening ability in groups of students who have studied with metacognitive and those who studied with cognitive strategies?

2. What is the difference in Arabic listening ability between groups of students who have extroverted and introverted personalities?

3. What are the interactions between learning strategies and personality towards Arabic listening ability?

4. What are the differences between Arabic listening ability in groups of students who have studied with metacognitive and cognitive strategies in groups of students who have introverted personalities?

5. What are the differences between Arabic listening ability in groups of students who have studied with metacognitive and cognitive strategies in groups of students who have extroverted personalities?

6. What are the differences between Arabic listening ability ingroups of students who have extroverted and introverted personalities in groups of students learn using metacognitive strategies?

7. What are the differences between Arabic listening ability between groups of students who have extroverted and introverted personalities in groups of students who learn using cognitive strategies?

\section{Method}

The research was conducted in the second semester of 2017/2018 academic year students who took the "Istima" 1 course in the Arabic Language Education Study Program, State University Jakarta. The research method is an experimental method using factorial group design two $2 \times 2$ categories. It is one type of research that tests hypotheses to determine causal relationships. ${ }^{16}$

Table 1. Research Treatment By Level Design

\begin{tabular}{ccc}
\hline \multirow{2}{*}{ Personality (B) } & \multicolumn{2}{c}{ Learning Strategy (A) } \\
\cline { 2 - 3 } & metacognitive $\left(\mathrm{A}_{1}\right)$ & Cognitive $\left(\mathrm{A}_{2}\right)$ \\
\hline Introvert $\left(\mathrm{B}_{1}\right)$ & $\mathrm{A}_{1} \mathrm{~B}_{1}$ & $\mathrm{~A}_{2} \mathrm{~B}_{1}$ \\
\hline Extrovert $\left(\mathrm{B}_{2}\right)$ & $\mathrm{A}_{1} \mathrm{~B}_{2}$ & $\mathrm{~A}_{2} \mathrm{~B}_{2}$ \\
\hline
\end{tabular}

${ }^{16}$ L.R. Gay, E. Mills Geoffrey, Peter Airasian, Types of Text in Books for Learning Arabic as a Second Language: A Document Analysis, (New York: Pearson, 2009). 
The sampling technique is a multistage cluster random sampling technique. The steps of the sampling technique in the study are; 1) research activities determine the place of research in the Arabic Language Education Study Program, Universitas Negeri Jakarta; 2) The sampling technique was purposive sampling due to consideration of determining the number of research classes, namely the second semester students as much as 4 classes, namely 2 control classes and 2 experimental classes; 3) the four classes were divided into two experimental classes accepting metacognitive learning strategies and two control classes receiving cognitive learning strategies; 4) each class group is divided into 2 groups, namely groups consisting of students who have introverted personalities and have extroverted personalities. The division of introverted and extroverted personalities is based on the results of data analysis obtained from questionnaire dissemination, then the results of the scores ranked; 5) the score obtained is rated as many as $27 \%$ of the upper group that has an introverted personality, were as $27 \%$ of the lower group were extroverted. This refers to Guilford's recommendation (Jusup, 2014); and 6) the control group consisted of 22 students and the experimental group consisted of 22 students. In each cell were 11 students for those who had introverted and extroverted personalities.

The research instrument consisted of two, among others (1) Arabic listening ability as a dependent variable used essay test; and (2) personality as an attribute variable used questionnaires. Here is the component of Arabic listening test.

Table 2. Component of the Arabic Listening Test

\begin{tabular}{lllc}
\hline Component & \multicolumn{1}{c}{ Indicator } & \multicolumn{1}{c}{ Types of } & Skor \\
\hline Cognitive & $\begin{array}{l}\text { Mechanical skills, knowledge of the language, } \\
\text { transfer, communication, and criticism. }\end{array}$ & $\begin{array}{l}\text { Multiple } \\
\text { chooses }\end{array}$ & True $=1$ \\
Affective & $\begin{array}{l}\text { Knowledge of listening, motivation to listen, } \\
\text { appropriate and effective performance }\end{array}$ & False \\
& Internal action & \\
\end{tabular}

The validity of the Arabic listening test is not empirically tested but it is based on a validity test conducted rationally by experts (Interpreters) consisting of three panelists. The reliability test is done by test-retest using the Product Moment correlation technique. Here is the component of the questionnaire for personalities instrument. 
Table 3. Component of Personalities Questionnaire

Component

Indicator

Extrovert Introvert

1. Social relationship and 1 . Needing someone else

1. Avoiding friend interaction

2. Having a desire is influenced

2. Solitude and influences the outside world

3. Subjectively influenced the world

3. Getting along easily

4. Do not like groups

4. Family

5. Grouping

2. Communication ways

1. Opening to others

2. Able to build two-way

1. Closed to other people

3. Activity communication

1. Free and lots of activities

5. Difficult to get along

2. Relax

3. Optimistic to achieve desired

4. How to solve the

4. Easy going problem

1. Prefer acting

2. Always take action instead of thinking

3. Confidence

2. Don't talk much

1. Reliable

2. Serious

3. Pessimists

4. Quiet

1. Thinking of solutions to problems rather than acting

2. Like concentration and silence

3. More thinking of himself

4. Think deeply

4. Convey what you want to

In this study, there are two ways to the validity of research design. The first is control of internal validity. The process of controlling internal validity consists of; a) experimental mortality; b) maturation; c) testing; d) instrument; e) the influence of statistical regression; f) location; and g) the influence of interaction with selection. The second is control of external validity. The process of controlling external validity consists of control of the population and ecological validity. The data analysis technique of this study is the 2 ways variance analysis technique at the significance level $\alpha=0.05$ and $\alpha=0.01$. If the results of data analysis found an interaction, the researcher continues to analyze the data with the Dunnet t-Test. The normality test uses the Liliefors test, while the homogeneity test uses the Bartlett test at the level of confidence $\alpha=0.05$. 
Arabiyât Jurnal Pendidikan Bahasa Arab dan Kebahasaaraban, 6 (2), 2019

\section{Result} analysis.

The following is a presentation of data from the calculation of research data

Table 4. Recapitulation of the Score of Arabic Listening Ability

\begin{tabular}{|c|c|c|c|}
\hline$B A$ & $\mathbf{A}_{1}$ & $\mathbf{A}_{2}$ & Total \\
\hline \multirow{6}{*}{$\mathbf{B}_{1}$} & $\sum Y_{11}=950$ & $\sum Y_{21}=902$ & $\sum Y_{B 1}=1852$ \\
\hline & $n_{11}=11$ & $n_{21}=11$ & $n_{B 1}=22$ \\
\hline & $\bar{Y}_{11}=86,36$ & $\bar{Y}_{21}=82$ & $\bar{Y}_{B 1}=168.36$ \\
\hline & $\sum Y_{11^{2}}=82180$ & $\sum Y_{21^{2}}=74476$ & $\sum Y_{B 1^{2}}=156656$ \\
\hline & $S_{11^{2}}=13,45$ & $S_{21^{2}}=51,2$ & $S_{B 1^{2}}=64.65$ \\
\hline & $S_{11}=3.67$ & $S_{21}=7,15$ & $S_{B 1}=10.82$ \\
\hline \multirow{6}{*}{$\mathbf{B}_{2}$} & $\sum Y_{12}=717$ & $\sum Y_{22}=844$ & $\sum Y_{B 2}=1561$ \\
\hline & $n_{12}=11$ & $n_{22}=11$ & $n_{B 2}=22$ \\
\hline & $\bar{Y}_{12}=65.18$ & $\bar{Y}_{22}=76.73$ & $\bar{Y}_{B 2}=141.91$ \\
\hline & $\sum Y_{12^{2}}=46977$ & $\sum Y_{22^{2}}=65030$ & $\sum Y_{B 2^{2}}=112007$ \\
\hline & $S_{12^{2}}=24.16$ & $S_{22^{2}}=27.22$ & $S_{B 2^{2}}=51.38$ \\
\hline & $S_{12}=4.92$ & $S_{22}=5.22$ & $S_{B 2}=10.14$ \\
\hline \multirow{6}{*}{ Total } & $\sum Y_{A 1}=1667$ & $\sum Y_{A 2}=1746$ & $\sum Y_{T}=3413$ \\
\hline & $n_{A 1}=22$ & $n_{A 2}=22$ & $n_{T}=44$ \\
\hline & $\bar{Y}_{A 1}=151.54$ & $\bar{Y}_{A 2}=158.73$ & \\
\hline & $\sum Y_{A 1^{2}}=129157$ & $\sum Y_{A 2^{2}}=139506$ & \\
\hline & $S_{A 1^{2}}=37.61$ & $S_{A 2^{2}}=78.42$ & \\
\hline & $S_{A 1}=8.59$ & $S_{22}=12.37$ & \\
\hline
\end{tabular}

The result of the study shown that metacognitive learning strategies are better than cognitive learning strategies. The average score of students studied using the metacognitive learning strategy was 81.54 and those who studied with cognitive strategies were 73.59. Both scores have shown better development. Overall of the average score of students' Arabic listening ability that had an extrovert personality of 84.18 is better than an introvert personality. While the result of the hypothesis test is;

1. $\mathrm{F}_{\text {-count }}(\mathrm{R})>\mathrm{Ft}(0.05)=17.7>4.085$, so Ho is rejected, there are significant differences between row. This means that there are differences in students' Arabic listening ability who are taught with metacognitive and cognitive learning strategies.

2. $\quad \mathrm{F}_{\text {-count }}(\mathrm{C})>\mathrm{Ft}(0.05)=246.7>4.085$, so Ho is rejected, there are significant differences between columns. This means that there are differences in 
Arabiyât Jurnal Pendidikan Bahasa Arab dan Kebahasaaraban, 6 (2), 2019

students' Arabic listening ability between students who have an extroverted and introverted personality.

3. $\mathrm{F}_{\text {-count }}(\mathrm{i})>\mathrm{Ft}(0.05)=89.6>4.085$, so Ho is rejected, there is an interaction between column and row factors. This means that there is an influence of interaction between learning strategies and personality.

4. The influence of independent variables on the dependent variable is large. The influence of learning strategies, personality, and interaction of learning strategies with personality on Arabic listening ability is expressed by the following formula.

a. Effect of learning strategies

$$
\begin{aligned}
\hat{\mathrm{W}}^{2}= & \frac{\mathrm{db}\left(\mathrm{F}_{0}(\mathrm{~A})-1\right)}{\mathrm{db}\left(\mathrm{F}_{0}(\mathrm{~A})-1\right)+\mathrm{N}} \\
= & \frac{1(17.7-1)}{1(17.7-1)+44}=0.2751
\end{aligned}
$$

This means that the learning strategy can explain $27.51 \%$ of the variation in students' Arabic listening ability

b. Personality Influence

$$
\begin{aligned}
\hat{\mathrm{W}}^{2}= & \frac{\mathrm{db}\left(\mathrm{F}_{0}(\mathrm{~B})-1\right)}{\mathrm{db}\left(\mathrm{F}_{0}(\mathrm{~B})-1\right)+\mathrm{N}} \\
= & \frac{1(246.7-1)}{1(246.7-1)+44}=0,8481
\end{aligned}
$$

This means that the type of personality can explain $84.81 \%$ of the variation in students' Arabic listening ability.

c. Effect of interaction between learning strategies and personality $\hat{\mathrm{W}}^{2}=\underline{\mathrm{db}\left(\mathrm{F}_{0}(\mathrm{AB})-1\right)}$

$$
\begin{aligned}
& \frac{\mathrm{db}\left(\mathrm{F}_{0}(\mathrm{AB})-1\right)+\mathrm{N}}{(89.6-1)} \\
1 & (89.6-1)+44
\end{aligned}=0,6682
$$

This means that the interaction of learning strategies and types of personality can explain $66.82 \%$ of the variation in students' Arabic listening ability. Since there are differences in analysis, the analysis process is continued to determine the level of further differences, which can be solved through One way ANOVA analysis. This procedure requires the conversion of data in four treatments or groups to be tested by the One way ANOVA procedure. From the results of 2 -way anova analysis, it has been obtained: $J K(A B)=698.96$,

$$
\begin{aligned}
& \mathrm{JK}(\mathrm{A})=138.04, \mathrm{JK}(\mathrm{B})=1924.7, \mathrm{RJK}(\mathrm{D})=7.8, \\
& \mathrm{JK}\left(\mathrm{A}_{\mathrm{x}}\right) \quad=\mathrm{JK}(\mathrm{AB})+\mathrm{JK}(\mathrm{A})+\mathrm{JK}(\mathrm{B})
\end{aligned}
$$




$$
\begin{aligned}
& =698.96+138.04+1924.7 \\
& =2761,8 \\
& \mathrm{db}\left(\mathrm{A}_{\mathrm{x}}\right)=\mathrm{n}_{\mathrm{ax}}-1=4-1=3 \\
& \operatorname{RJK}\left(A_{x}\right) \quad=\coprod K\left(A_{x}\right)=\underline{2761,8}=920,6 \\
& \mathrm{n}_{\mathrm{ax}}-1 \quad 3 \\
& \left.\operatorname{RJK}\left(\mathrm{D}_{\mathrm{x}}\right) \quad=\mathrm{RJK}(\mathrm{D})=7.8 ; \mathrm{db} \mathrm{D}\right)=40 \\
& \mathrm{~F}_{0}=\underline{\mathrm{RJK}}\left(\mathrm{A}_{\mathbf{x}}\right)=\underline{920,6}=23,015 \text {, } \\
& \mathrm{RJK}\left(\mathrm{D}_{\mathrm{x}}\right) \quad 40
\end{aligned}
$$

Comparing with $\mathrm{F}_{(0,05 ; 3 ; 40)}=2,84$

So $\mathrm{F}_{0}>\mathrm{Ftab}$ means $\mathrm{Ho}$ is rejected. Thus, there are differences in the average score between the four treatment groups (cells). Furthermore, further tests were carried out with the Dunnet t-test with t-tab $=\mathrm{t}(\alpha ; \mathrm{d}(\mathrm{D}))=\mathrm{t}(0.05 ; 40)=2.021$

a. The difference in groups $A_{1} B_{1}$ and $A_{2} B_{1}$ :

Hypothesis:

$\mathrm{H} 0: \mu \mathrm{A}_{1} \mathrm{~B}_{1} \leq \mu \mathrm{A}_{2} \mathrm{~B}_{1}$

$$
\begin{aligned}
& \mathrm{H} 1: \mu \mathrm{A}_{1} \mathrm{~B}_{1}>\mu \mathrm{A}_{2} \mathrm{~B}_{1} \\
& \begin{aligned}
\left.\mathrm{t}_{\mathrm{o}}\left(\mathrm{a}_{1} \mathrm{~b}_{1} \times \mathrm{x}_{2} \mathrm{~b}_{1}\right)=\underline{\mathrm{I}}_{\underline{11}}-\dot{\mathrm{X}}_{21} \frac{\mathrm{I}}{\sqrt{\mathrm{RJK}}(\mathrm{D})\left(1 / \mathrm{n}_{11}\right.}+1 / \mathrm{n}_{21}\right) \\
=\underline{\mathrm{I} 86,36-82 \quad \mathrm{I}} \\
\sqrt{7.8(0.09+0.09)} \\
=\underline{4.36}=3.679
\end{aligned}
\end{aligned}
$$

Because $t_{0}=3.679>t_{\text {tab }}=2,021$ then Ho is rejected, so students' Arabic listening ability that taught with metacognitive learning strategies is higher than students taught with cognitive learning strategies, which have an extroverted personality.

b. The difference in groups $A_{1} B_{2}$ and $A_{2} B_{2}$ :

Hypothesis

H0: $\mu A_{1} B_{2} \geq \mu A_{2} B_{2}$

$$
\begin{aligned}
& \mathrm{H} 1: \mu \mathrm{A}_{1} \mathrm{~B}_{2}<\mu \mathrm{A}_{2} \mathrm{~B}_{2} \\
& \mathrm{t}_{\mathrm{o}}\left(\mathrm{a}_{1} \mathrm{~b}_{1} \times \mathrm{a} \mathrm{a}_{2} \mathrm{~b}_{1}\right)=\underline{\mathrm{I}}_{\underline{12}}-\dot{\mathrm{X}}_{22} \frac{\mathrm{I}}{\sqrt{\mathrm{RJK}(\mathrm{D})})\left(1 / \mathrm{n}_{12}+1 / \mathrm{n}_{22}\right)} \\
& =\frac{\mathrm{I} 65,18-76.73 \mathrm{I}}{\sqrt{7.8(0.09+0.09)}} \\
& =\underline{-11.52 .}=-9.72
\end{aligned}
$$


Because $t_{0}=-9.72>t_{\text {tab }}=2,021$ then Ho is rejected, so students' Arabic listening ability that taught with metacognitive learning strategies is lower than students taught with cognitive learning strategies, which have an introverted personality.

c. The difference in groups $A_{1} B_{1}$ and $A_{1} B_{2}$ :

Hypothesis

$\mathrm{H} 0: \mu \mathrm{A}_{1} \mathrm{~B}_{1} \leq \mu \mathrm{A}_{1} \mathrm{~B}_{2}$

$$
\begin{aligned}
& \mathrm{H} 1: \mu \mathrm{A}_{1} \mathrm{~B}_{1}>\mu \mathrm{A}_{1} \mathrm{~B}_{2} \\
& \mathrm{t}_{\mathrm{o}}\left(\mathrm{a}_{1} \mathrm{~b}_{1} \times \mathrm{a}_{2} \mathrm{~b}_{1}\right)=\underline{\mathrm{I}}_{\underline{11}}-\dot{X}_{12} \frac{\mathrm{I}}{\sqrt{\mathrm{RJK}(\mathrm{D})})\left(1 / \mathrm{n}_{11}+1 / \mathrm{n}_{21}\right)} \\
& =\underline{\mathrm{I} 86,36-65.18 \mathrm{I}} \\
& =\underline{\sqrt{ } 7.8(0.09+0.09)} \\
& =\underline{21.18 .}=17.873
\end{aligned}
$$

\subsection{5}

Because $\mathrm{t}_{\mathrm{o}}=17.873>\mathrm{t}_{\text {tab }}=2,021$ then Ho is rejected, so students' Arabic listening ability that have an extroverted personality is higher than students who have an introverted personality that is taught with metacognitive learning strategies

d. The difference in groups $\mathrm{A}_{2} \mathrm{~B}_{1}$ and $\mathrm{A}_{2} \mathrm{~B}_{2}$ :

Hypothesis

$\mathrm{H} 0: \mu \mathrm{A}_{2} \mathrm{~B}_{1} \geq \mu \mathrm{A}_{2} \mathrm{~B}_{2}$

$$
\begin{aligned}
& \mathrm{H} 1: \mu \mathrm{A}_{2} \mathrm{~B}_{1}<\mu \mathrm{A}_{2} \mathrm{~B}_{2} \\
& \mathrm{t}_{\mathrm{o}}\left(\mathrm{a}_{1} \mathrm{~b}_{1} \times \mathrm{a}_{2} \mathrm{~b}_{1}\right)=\underline{\mathrm{I}}_{\underline{2} 1}-\dot{\mathrm{X}}_{22} \underline{\mathrm{I}} \underline{\sqrt{\mathrm{RJK}(\mathrm{D})}\left(1 / \mathrm{n}_{11}+1 / \mathrm{n}_{21}\right)} \\
& =\underline{\mathrm{I} 82-76.73 \mathrm{I}} \\
& =\underline{\sqrt{ } 7.8(0.09+0.09)}=4.447
\end{aligned}
$$

1.185

Because $\mathrm{t}_{\mathrm{o}}=4.447>\mathrm{t}_{\mathrm{tab}}=2,021$, Ho is rejected, so students' Arabic listening ability that has an extroverted personality is lower than students who have an introverted personality who are taught with cognitive learning strategies.

\section{Discussion}

Based on the data of findings, it shows that the implementation of the metacognitive and cognitive strategy has increased the students' motivation to learn Arabic listening for both introvert and extrovert personalities. This means that students who have the type of personality will have different listening abilities. Therefore, the personality is directly related to the way students in managing 
themselves. Self-management in learning is also influenced by different learning strategies. Thus, between students and teachers is a concept of unity that must be fostered, so that learning objectives can be achieved and students have the ability according to the expertise of the study program taken. Problems that have been found in Arabic listening learning are related to self-regulated learning have been overcome by mapping of students' personality and the use of learning strategies are appropriate with their needs.

The application of metacognitive learning strategies has required students to go through stages in a sequential manner of planning to determine which messages have been heard, establish messages that are following the context and review predetermined messages. So, this method can be done repeatedly which can provide habituation to the process of Arabic listening. So, this learning strategy requires students to think critically and creatively. Besides, it has also built student learning independently.

The process of cognitive learning strategy requires students to be able to use information that they already have in understanding the meaning or message which they have heard. The strategy requires students to think hard, serious, and have high thinking patterns. Nevertheless, cognitive strategies have also demanded a continuous learning pattern and self-regulation in self-regulated learning.

Therefore, the application of these two strategies is combined with the concept of self-regulation of students in learning (self-regulated learning). Because self-regulation is a part that can be associated with the application of metacognitive and cognitive strategies. As explained in previous research that self-regulated learning has built a lot of interest among academics and psychologists because research shows that it has a positive effect on students' academic performance. Experts suggest that "meta-cognitive awareness" influences one's thinking and can lead to deeper learning and improved performance, especially among students who experience problems in learning. ${ }^{17}$ The same research has also been proven by Yusri, et.al. ${ }^{18}$ This study investigated cognitive and metacognitive strategies in learning Arabic listening among students at Universiti Teknologi MARA (UiTM), Malaysia. The concept of this strategy comes from an independent learning framework, which consists of five components, namely training, elaboration, organization, critical thinking, and metacognitive strategies. Similar to the study, this study also found the effectiveness of the five components of independent learning during the experimental process in the classroom.

Also, the emphasis on independent learning and self-regulated learning is based on the consideration that if students have a thinking pattern, and the right

17 R. Mahadi, \& G. Subramaniam, "The Role Of Metacognitive Self Regulated Learning Strategies In Enhancing Language Performance: A Theoretical And Empirical Review", Journal of Asian Scientific Research, Vol. 3, No. 6, 2013, 570-577.

${ }^{18}$ G. Yusri, N. M. Rahimi, P. M. Shah, \& W. H. Wah, "Cognitive and metacognitive learning strategies among Arabic language students”, Interactive Learning Environments, Vol. 21, No. 3, 2013, 290 300. 
learning pattern will have a big influence on achieving learning success. Moreover, both of these strategies require students to be able to think critically and learn continuously. However, this can be realized when students are also by their learning needs. Moreover, listening to learning requires high concentration. Students must listen to audio carefully, managing the information becomes the right message. With the combination of the application of the two strategies applied to the two types of personality, students can provide enthusiasm and motivation in learning. Besides, students can also concentrate easily because they have been grouped and combined according to the type of student personality. Students with introverted personalities need time and concentration in understanding meaning. This personality also has strong internal stimuli in giving concentration to learning. But the closed character makes it difficult for students to discuss when experiencing problems in understanding meaning.

On the other hand, students with extroverted personality are easier to discuss and optimistic about doing all tasks. The success of this research has also been proven by previous researchers. But in this study, it has found something different from previous research. In this study, it has been supported by the management concept of self-regulation of students to study, so that they have no difficulty when receiving treatment during the learning process of Arabic listening. Since the listening process requires intensive practice. As in research, ${ }^{19}$ it has been researching to improve the Arabic listening ability through the practice of understanding strategies. Rahimi, et.al has the same research that Arabic listening among teacher is easy when they do as continue. ${ }^{20}$ So, the listening process is easier for students to do when they want to practice continuously and regularly.

However, the practice becomes worthless when students lack motivation for learning. Students have a personality is not managed well. Therefore, it has less effect on listening ability. In the research of Ghaemi and Sabokrouh ${ }^{21}$ or Alavinia \& Mollahossein $^{22}$ have proven that personality differences influence the implementation of listening learning strategies. Besides that, language learning is influenced by individual characteristics and variations of language learning outcomes.

However, if it is understood as a whole that influences the success or achievement of students not only comes from the students themselves or the use of

${ }^{19}$ F.M. al-Hawamidah \& A.M. al-Khawalidah, "The Estimation Degree of Jordanians Arabic Language Teachers in Upper Basic Stages of Their Listening Comprehension Teaching Strategies Practices", IUG Journal of Educational and Psychological Studies, Vol. 24, No. 1, 2016, 74-90.

${ }^{20}$ N. M. Rahimi, M. S. Kamis, \&, W. Normeza, "The misconception of Arabic language listening skills among teachers", Social Sciences (Pakistan), Vol. 8, No. 4, 2013, 347-350.

21 F. Ghaemi, \& F. Sabokrouh, "The Relationship between Personality Traits and Metacognitive Listening Strategies among Iranian EFL Learners, ELT”, Voices- International Journal for Teachers of English, Vol. 5, No. 2, 2015.

22 P. Alavinia, \& H. Mollahossein, “On the Correlation between Iranian EFL Learners' Use of Metacognitive Listening Strategies and Their Emotional Intelligence”, International Education Studies, Vol. 5, No. 6, 2012, 189. 
learning strategies, but learning resources become an important part that cannot be separated. In this study, the experimental activities also used teaching materials that were not easy. This means that the teaching material provided is adjusted to the level and given a higher level of material and authentic. So that it can stimulate the mindset of students to become wider. As has been done in the Hamada study. ${ }^{23}$

In other research, Serri, Boroujeni, \& Hesabi, ${ }^{24}$ it has been proven that students use cognitive and metacognitive strategies more often in listening comprehension than affective/social strategies. It has also been distinguished by different levels of personality or motivation. Similar to the research that has been done by Akyol, Sungur, \& Tekkaya ${ }^{25}$ which has focused on the effectiveness of cognitive and metacognitive strategies for improving student achievement, whereas in the study Khezrlou $^{26}$ which has examined the relationship between cognitive and metacognitive strategies at different levels of education and age. The results showed that there was a significant influence strategy of learning and personality on Arabic listening skills. From the results of these studies, it is clear that there is a fairly good influence on the characteristics of student personality in achieving learning achievement in Arabic.

In the study Muharrami, Setiyadi, \& Hasan, ${ }^{27}$ it was concluded that there were differences between introverted and extroverted students in achieving listening skills and introverted students had better attainment in listening. During the learning process in the classroom, researchers have used the form of group learning, so that the application of cognitive and metacognitive strategies becomes more effective. Nussbaum $^{28}$ has examined learning approaches that utilize introvert and extrovert personalities during the process of argumentative discussion. The results show that there are different influences with different levels of personality. The same thing has been applied in research Travolta, Mulyadi, \& Imranuddin to test the level of listening ability in English. ${ }^{29}$ The results of this study are, (1) there are significant differences between introverted and extroverted students towards the score of English listening, (2) introverted students have better grades in English listening than extroverted

${ }^{23}$ Y. Hamada, "Improvement of Listening Comprehension Skills through Shadowing with Difficult Materials”, Spring, Vol. 8, No. 1, 2011, 139-162.

${ }^{24}$ F. Serri, A. J. Boroujeni, \& A. Hesabi, "Cognitive, Metacognitive, and Social/Affective Strategies in Listening Comprehension and Their Relationships with Individual Differences", Theory \& Practice in Language Studies, Vol. 2, No. 4, 2012, 843-849.

${ }_{25}$ G. Akyol, S. Sungur, \& C. Tekkaya, "The contribution of cognitive and metacognitive strategy use to students' science achievement”, Educational Research and Evaluation, Vol. 16, No. 1, 2010, 1-21.

${ }^{26}$ S. Khezrlou, "The Relationship between Cognitive and Metacognitive Strategies, Age, and Level of Education", The Reading Matrix, Vol. 12, No. 1, 2012, 50-61.

${ }^{27}$ M. L. Muharrami, A. B. Setiyadi, \& H. Hasan, "A Comparative Study Between Introvert And Extrovert Students Personality In Listening Achievement”, U-JET, Vol. 2, No. 8, 2013.

28 E. M. Nussbaum, "How Introverts versus Extroverts Approach Small-Group Argumentative Discussions", The Elementary School Journal, 2002, The University of Chicago Press.

${ }_{29}$ Y. Travolta, M. Mulyadi, \& I. Imranuddin, "A Comparative Study On Introvert And Extrovert Students Personality In English Listening Scores", 2017 Retrieved from http://repository.unib.ac.id/14366/ 
students. So, it can be concluded that different personalities will affect the level of ability in mastering foreign language skills such as Arabic, English, French, and so on. In the study Mall-Amiri \& Nakhaie, ${ }^{30}$ it was proven that there were differences in student performance towards completing assignments or listening and reading exercises.

Thus, the new thing presented in this research is the concept of developing more independent learning and self-regulating learning in the application of metacognitive and cognitive learning strategies. This is because metacognitive and cognitive learning has harmony and balance with personality. Self-regulation is the basis of students' personal character development to achieve learning goals. With an organized self, students become easier to receive learning.

\section{Conclusion}

The result of the analysis concluded that there is an interaction between learning strategies and personality towards the Arabic listening ability. So, the teacher can map learning strategies are in accordance with the students type of personality. Students' Arabic listening ability who study with metacognitive learning strategies is better than those who learn with cognitive learning strategies in groups of students who have extroverted personalities, while students' Arabic listening ability who learn with cognitive learning strategies is better than those who learn with metacognitive learning strategies in groups of students who have introverted personalities.

The study provides positive implications that can improve the teaching and learning process of Arabic listening is to better in learning quality. The implication is, 1) teacher can provide metacognitive learning strategies for students who have extroverted personalities, but the teacher can also provide these strategies to students who have introverted personalities through the addition and development of learning media. 2) The teacher can also provide cognitive learning strategies to students who have introverted personalities, while students who have extroverted personality can be increased by increasing the difficulty level of teaching material. 3) The teacher can make a map of teaching and learn in the classroom according to the learning strategy procedures used, but still adapted to the needs and environment of the school. 4) A teacher who teaches Arabic listening can easily determine learning strategies from the results of literature analysis and problems in the field. In addition, the determination is also based on the consideration of the learning objectives to be achieved, as has been studied in the Arabic Language Education study program at Jakarta State University. The teacher must also carefully understand the characteristics of students so that the teaching and learning process can listen smoothly. However, if the teacher is more creative then this learning strategy can be applied to other subjects or combined with other learning models or the use of other learning strategies. []

30 B. Mall-Amiri, \& N. Nakhaie, "Comparing the Performance of Extrovert and Introvert Intermediate Female EFL Learners on Listening and Reading Tasks", International Journal of Language Learning and Applied Linguistics World, Vol. 3, No. 3, 1, 2013, 1-29. 


\section{REFERENCES}

Akyol, G., Sungur, S., \& Tekkaya, C. "The contribution of cognitive and metacognitive strategy use to students' science achievement", Educational Research and Evaluation, Vol. 16, No. 1, 2010.

Alavinia, P. \& Sameei, A. "Potential Bonds between Extroversion/Introversion and Iranian EFL Learners' Listening Comprehension Ability", English Language Teaching, Vol. 5, No. 5, 2012.

Alavinia, P. \& Sameei, A. "Potential Bonds between Extroversion/Introversion and Iranian EFL Learners' Listening Comprehension Ability", English Language Teaching, Vol. 5, No. 5, 2012.

Alavinia, P. \& Mollahossein, H. "On the Correlation between Iranian EFL Learners' Use of Metacognitive Listening Strategies and Their Emotional Intelligence", International Education Studies, Vol. 5, No. 6, 2012.

Dajani, B. A. S., Mubaideen, S. \& Omari, F. M. A. "Difficulties of Learning Arabic for Non-native Speakers", Procedia - Social and Behavioral Sciences, Vol. 114, 2014.

Dajani, B. A. S. "Teaching the Arabic Language: Towards a New Beginning that Stimulates Creativity", Procedia - Social and Behavioral Sciences, Vol. 192, 2015.

Dwi, S. Kenali Dirimu, Yuk!! Wonosari: Laksana. 2014

Goh, C. C. 'A cognitive perspective on language learners' listening comprehension problems", The system, Vol. 28, No. 1, 2000.

Goh, C. English Language Teaching Materials Theory and Practice. ed. Nigel Harwood. Cambridge: Cambridge University Press, 2010.

Gay, L.R. Geoffrey, E. Mills, Airasian, Peter. Types of Text in Books for Learning Arabic as a Second Language: A Document Analysis. New York: Pearson, 2009.

Graham, S. "Listening comprehension: The learners' perspective", The system, Vol. 34, No. 2, 2006.

Ghaemi, F. \& Sabokrouh, F. "The Relationship between Personality Traits and Metacognitive Listening Strategies among Iranian EFL Learners, ELT", VoicesInternational Journal for Teachers of English, Vol. 5, No. 2, 2015.

Hamada, Y. "Improvement of Listening Comprehension Skills through Shadowing with Difficult Materials", Spring, Vol. 8, No. 1, 2011.

al-Hawamidah, F.M., A.M. al-Khawalidah. "The Estimation Degree of Jordanians Arabic Language Teachers in Upper Basic Stages of Their Listening Comprehension Teaching Strategies Practices", IUG Journal of Educational and Psychological Studies, Vol. 24, No. 1, 2016. 
Arabiyât Jurnal Pendidikan Bahasa Arab dan Kebahasaaraban, 6 (2), 2019

Khezrlou, S. "The Relationship between Cognitive and Metacognitive Strategies, Age, and Level of Education", The Reading Matrix, Vol. 12, No. 1, 2012.

Khamis Dakwar,R. Ahmar, M. Farah, R. \& Froud, K. "Diglossic aphasia and the adaptation of the Bilingual Aphasia Test to Palestinian Arabic and Modern Standard Arabic", Journal of Neurolinguistics, Vol. 47, 2018.

Mohamed, A. H. H. “The Relationship Between Metacognition and Self-regulation in Young Children”, Procedia - Social and Behavioral Sciences, Vol. 69, 2012.

Mahadi, R. \& Subramaniam, G. "The Role Of Metacognitive Self Regulated Learning Strategies In Enhancing Language Performance: A Theoretical And Empirical Review", Journal of Asian Scientific Research, Vol. 3, No. 6, 2013.

Mall-Amiri, B., \& Nakhaie, N. "Comparing the Performance of Extrovert and Introvert Intermediate Female EFL Learners on Listening and Reading Tasks", International Journal of Language Learning and Applied Linguistics World, Vol. 3, No. 3, 1, 2013.

Muharrami, M. L., Setiyadi, A. B., \& Hasan, H. "A Comparative Study Between Introvert And Extrovert Students Personality In Listening Achievement", $U$ JET, Vol. 2, No. 8, 2013.

Nussbaum, E. M. "How Introverts versus Extroverts Approach Small-Group Argumentative Discussions", The Elementary School Journal, 2002, The University of Chicago Press.

O’Malley, J. M., \& Chamot, A. U. Learning Strategies in Second Language Acquisition. Unites Stated of Americ: Cambridge University Press. 1995

Rahimi, N. M., Kamis, M. S. \&, NormezaW. “The misconception of Arabic language listening skills among teachers", Social Sciences (Pakistan), Vol. 8, No. 4, 2013.

Serri, F., Boroujeni, A. J. \& Hesabi, A. "Cognitive, Metacognitive, and Social/Affective Strategies in Listening Comprehension and Their Relationships with Individual Differences", Theory \& Practice in Language Studies, Vol. 2, No. 4, 2012.

Selamat, S. \& G. K. Sidhu. "Enhancing Listening Comprehension: The Role of Metacognitive Strategy Instruction (MetSI)", Procedia - Social and Behavioral Sciences, Vol. 90, 2013.

Travolta, Y., Mulyadi, M., \& Imranuddin, I. "A Comparative Study On Introvert And Extrovert Students Personality”, English Listening Scores, 2017.

Vahdany, F., E. Akbari, F. Shahrestani, \& A. Askari. "The Relationship between Cognitive and Meta-cognitive Strategy Use and EFL Listening Test Performance", Theory and Practice in Language Studies, Vol. 6, No. 2, 2016. 
Ara6iyât Jurnal Pendidikan Bahasa Arab dan Kebahasaaraban, 6 (2), 2019

Yusri, G., N. M. Rahimi, P. M. Shah, \& W. H. Wah, "Cognitive and metacognitive learning strategies among Arabic language students", Interactive Learning Environments, Vol. 21, No. 3, 2013.

$\ddot{Y} z$, Hüseyin. "The Importance of Personality Traits in Students: Perceptions of Metacognitive Awareness", Procedia-Social and Behavioral Sciences, Vol. 232. 2016.

Yıldırım, S., \& Ö. Yıldırım. "Yabanci Dil Öğreniminde Dinleme Becerisinin Önemi Ve Yabanci Dil Öğrenenlerin Yaşadiği Dinleme Anlama Problemleri: Bir Alanyazin Değerlendirmesi”, Abant İzet Baysal Üniversitesi Eğitim Fakültesi Dergisi, Vol. 16, No. 4, 2016. 